\title{
Writing Instructional Model for Elementary Education Program
}

\author{
Rohana \\ Elementary Education Program of Education Faculty \\ State University of Makassar, Indonesia \\ E-mail: rhnsyamsuddin @gmail.com
}

Received: December 10, 2015 Accepted: December 27, 2015 Published: December 28, 2015

doi:10.5296/ijele.v4i1.8791 URL: http://dx.doi.org/10.5296/ijele.v4i1.8791

\begin{abstract}
The main objective of this research is to develop an instructional model of narrative writing in English for students of Elementary Education Program (PGSD). This research conducted at of Elementary Education Program in 2013/2014, the research was carried out through research and development (R\&D) method. The qualitative data related to respondents in general view on the model developed and that of the instructional model of narrative writing. The result of the field testing through one group pretest-post-test design showed that the student post-test average writing scores were significantly greater than those of the pretest. The result of testing through pretest-post-test works showed that the student post-test average scores in the experimental groups were significantly greater than those of in the control groups. The material of writing could increase student competence in writing narrative text that. "Significantly; the experts agreed to the theoretical design used develop the instructional model of narrative writing.
\end{abstract}

Keywords: writing, narrative, instructional 


\section{A. Introduction}

\section{Background of the Problem}

In learning English as the foreign language, we have to know the four basic skills and comprehension. The four skills are reading, speaking, writing, and listening. In learning English, writing is the most difficult shall to mastery because writing consists of other skills and language components, such as organization, vocabulary, and structure. Furthermore,

Donn 'Byrne (1984: 3) stated that," We can now begin to see why writing is commonly a

difficult activity for most people, both in the mother tongue and in a foreign language. We look at the problems which are caused by writing under three heading; psychological, linguistic, and cognitive, although these inevitably overlap to some extent."

Writing is application of intellectually, would share anything and make changes in many aspects of life by their writing, writing can measure how many products of intellectual people produced by the country. We know that many books needed not only for education, but also economics, politics, religion, and other aspects, but in general we still adopt from foreign book. This is a proof of the lack writer in our country. Actually, Indonesia has many intellectual people with their skill and knowledge; however most of them are not skilled to apply their knowledge in writing book.

Writing is an activity that can be called as Re-creation and Recreation Richards (1986: 21) stated that, "To re-create means to give fresh life to something. Whenever someone paints a picture or writes a poem or even expresses an opinion that person is using his or her imagination to see the world a little differently anyone else sees it. Writing is the means by which your choice of what to focus on and give urgent emphasize to, becomes a shared experience. Writing can also give both emotional and aesthetic pleasure; this, we might call the recreational as well as the re-creation aspects of writing." There are many ways to share the feeling by writing as re-creation and recreation in to writing product writing products can be found anywhere, for example, when we go to the store books we can find books and other writing products; such as, magazine, tabloid, story book, biography, etc.

College students should master writing skill because there are generations who will give contribution to the future by their knowledge and skills. Students can share their knowledge and experience by providing books and articles. In this case, students can make good arrangements and write experience only by learning writing skills, especially narrative writing. They must have good ability in it. Here, learn to make narrative essay writing is very important because of some aspects; narrative essay will help students to find the problems around them in the past or already happened, they have more ideas to solve the problems because they learn from experiences. Furthermore, students are able to make other kinds of writing products in order to be read by others and would make a better change for human life.

Narrative essays rely on concrete and sensory details to convey people's point of view. These details create a unified, forceful effect, a dominant impression in essay on reader. As one of the modes of expository writing, narrative offers the opportunity to think and write, to explain 
experiences lead to some important realization or conclusion about their lives or about the world, in general. Through the narrative essay, people have the chance to record and share those experiences as a means to substantiate their new understanding, by mastering the narrative essay writing, college students will be more productive writer, because they know how to order their experience and more intelligible in exploring idea to be good writers.

The biggest challenge for teachers translated writing; this occurs when the English learners develop their idea in native language and then try to translate them into English. The writing is fully of inaccurate verb tenses and unintelligible sentences. The chaotic structure and grammar make the writing difficult to understand. This response indicates little understanding of the narrative task. Instead, the writer provides some observations about getting attention, but overlooks the need to develop a story. The writing does not establish an appropriate time or place, and there is no movement through time in a chronological sense. Ideas seem to be irrelevant due to their vagueness and/or weak connection to the writing task (attention is something that is hard to do). Also, the response shows little sense of audience and minimal author involvement. The writer begins this fairly sustained response with an acknowledgment of being the center of attention on numerous occasions. However, the response indicates little understanding of the assigned narrative task. Brian (2009) Responding to another's writing is always a challenging task, praise, question and wish solves dilemmas of tone by adopting positive language that strengthens the writer's

Syah (2006) writing assignments are primarily template assignment that prescribes the form and the content of composition; the writing process is often prescribed also as linear and sequential process. Carrol (1982) Writing a good composition is not easy, we must follow many step, the writing steps (1) Get some ideas, (2) organize the ideas, (3) write a plan or first draft (4) make changes, revise and rewrite a (5) make final plan, and check everything carefully or make sure that don't have any mistakes. Check grammar, spelling, and punctuation and choose a title. Donald and Gloria (2004) every language has its own grammatical system of written English .In order to help students write better, rewrite or reproduction written uses a special approach based on our analysis of written English and to improve student written.

Many instructional practices of narrative writing implemented by the still tend to emphasize the linguistic aspects and neglect student differences in the instruction of narrative writing. Besides, the students had lack of opportunities and guidance from teachers to practices writing. It is real that generally, the instructional practices of writing haven't changed from time to time though the English curriculum has been changed. Therefore, the development of instructional model of narrative writing is necessary.

Based on the description, it can be concluded that the main reason of conducting this research is that the instructional practices of narrative writing implemented by the teachers at Elementary Education Program of Education Faculty in State University of Makassar have not been directed to the achievement of the basic competence of writing in English as a foreign language. That main reason is evidenced in some phenomena of instructional practices of narrative writing at Elementary Education Program (PGSD). Firstly, the practices of writing instruction are still emphasized the mechanical and linguistic matters. Secondly, the practices 
of writing instruction have not given enough opportunities to the students indicated by the lack of guidance or others' responses.

In addition, the research is carried out as a response to recommendation on the importance of innovation on writing narrative. Finally, writing must be learning and taught since there is in one can take it for granted. One of the things to prepare by the teachers is an effective instructional model to teaching writing.

\section{2 .Statements of the Problem}

The problem of this research is formulated in the following question, "How is the instructional model of narrative writing in English for Elementary Education Program?"

\section{B. Theoretical Description}

\section{The Nature of Instructional Model}

The term 'instructional model' has various meanings. Richard and Renandya (2002: 303) use the term 'teaching model' to refer to the description about the instructional environment based on which teaching-learning process is carried out. Accordingly, teaching models are really models of 'learning' since the nature of teaching is to facilitate the students to experience learning process. So that it can be concluded that the idea of Joy and Weil about teaching model is similar to instructional model.

In addition, the term 'instructional model' is often used to refer to the conceptual framework functioning as the guideline for designing and implementing the teaching-learning activities (Winataputra, 2003:3) Furthermore, in relation to language instruction, Richards and Rogers (1986:20) define instructional model as the result of an effort to implement linguistics in language teaching-learning and to make the most effective relationship between linguistic and practice of language instruction

Richards, Platt and Webber (1985: 176) state that language instructional method is often defined as a way to teach language through a systematic procedure based on the view of how language is taught and learned. Instructional model is a design describing detail process and learning environment in which the student are possibly to interact so that learning process take place. in edition, instructional model talks not only the procedures of teaching-learning process (syntax) but also the instructional and nurturing effects, social system, reaction system, and supporting system to implement the teaching-learning activities.

Based on the description above, it can be concluded that instructional model of narrative writing can be defined as a conceptual framework used as a guideline for designing and implementing the teaching-learning activities of narrative writing. This conceptual framework contains the propositions to organize the teaching-learning of narrative writing.

A good instructional model consists of five main components: syntax, social system, reaction or response system, supporting system and instructional and nurturing effects. Syntax deals with the teaching-learning stages. In relation to the teaching-learning activities of writing, Richard and Renandya (2002: 303) state that the teaching-learning of writing generally 
comprises four basic stages: planning, drafting, revising and editing. More specifically, the stages of writing begin with selecting a topic, formulating ideas, planning and organizing, writing, revising, editing and rewriting to produce the final text. To write the narrative text through those stages, the students need to have the knowledge about the characteristics of the text: function, generic structure, and grammatical features used in the text. Thus, in the initial stage, the teaching-learning of narrative writing should be directed to build student' knowledge about narrative text, (Syah, 2006: 144).

The second component of a good instructional model is social system. It refers to the situation of the teaching-learning process. To make students learn writing in optimal way, they must be viewed as dynamic individuals who have some differences, including they are learning speed. Therefore, the teaching-learning activities of narrative writing should consider the student learning speed. Dulay, Burt and Krashen (1982: 262) state that learners learn most from their peers and from people with whom they identify. These need the implementation of teacher's role as trainer and a guide and student role as negotiators.

The third component of a good instructional model is reaction or response system refers to the way the teacher responds to the text written by the students in the teaching-learning process. Its main objective is to help the students write their best text based on their learning speed. To achieve this objective, the teacher should play as a trainer, guide and facilitator and the students are as negotiators (Brown, 2001: 340).

In addition, the teacher should avoid correction all the times to correct the grammatical errors since it is not an effective with the idea, Dulay, Burt and Krashen (1982: 263) state that each grammatical correction cannot help the learners to avoid making errors. Many students are often confused and frustrated with the correction or comments since they don't know what to do with them. Consequently, there are to continue writing. Brown (2001: 355-356) proposes that responses to the first draft should be directed on global errors and those of revised draft should be focused on local errors.

The fourth component is supporting system. This component refers to anything needed to support the process of teaching-learning. This can be in the form of instructional material and media. In relation to the teaching-learning of narrative writing, the supporting system can be dictionary, student worksheet or models of texts arranged in the form of student worksheet to learn.

The fifth, the former refers to the learning outcome directly achieved by the students as the direct effect of learning-teaching process (Winataputra, 2001:8). Since curriculum is one of pillars of language teaching-learning, the instructional effect must be in line with the curriculum.

Conversely, nurturing effect is the learning outcome as the effect to teaching-learning circumstance experience by the students (Winataputra, 2001: 8). This learning outcome is obtained without teacher direction. to influence can be the increase of student togetherness in completing the task, student braveness to express ideas in English orally, the student knowledge on language aspects or other language skills as the result of the situation promoted. 
Thus, nurturing effects naturally can be achieved due to the situation of teaching-learning process applied.

Based on the description above, it can be concluded that a good instructional model consists of five main components. They are syntax, social system, reaction system, supporting system and instructional and nurturing effects. Those components are related to each other. Therefore, this research develops the instructional model of narrative writing based on those components.

\section{Narrative Writing}

Narrative writing in categorized as fiction, which is based on imaginative events or stories that did not actually happen. The other category of writing is known as known as nonfiction, which would be all writing that is based on real facts. This usually consists of newspapers, essays, reports and other informative writing. However, some nonfiction can in fact tell a story, which would classify it as narrative writing. In the case of nonfiction, the story must be a true story with real people and events. Autobiographies and biographies are examples of nonfiction that is narrative writing, as they tell the real story of a person's life. Writing a sequence of sentences arranged in a particular order and linked together in certain ways (Byrne, 1984:1), and narrative is telling a story about events or actions (Smalley, in Brown 2004) an essay is a written argument which consists of an introduction, a statement of a thesis, support for that thesis, and a conclusion.

\section{Character of Narrative Text}

In addition to characters, (Byrne, 1984:15-17), every story must have a plot, or events that occur. Every story needs a plot, or events to give the characters something to react to. Usually, the plot consists of five components: the exposition, rising action, climax, falling action, and resolution.

One of the most important components of a story is the conflict. A conflict is any struggle between opposing forces. Imagine a story where there were no problems. The characters simply lived their happy lives with no troubles and nothing difficult to deal with. Would that story interest you? Conflict is very important to creating interest in stories.

Usually, the main conflict is between the protagonist and the antagonist, but that is not always the case. The struggles can exist between society, within a character, or even with acts of nature. There are two basic types of conflict: internal and external. Internal conflicts are the struggles that occur within a character, and external conflicts are the struggles of a character. These can occur between two characters, between characters and society, or between characters and natural events.

The setting is another component of narrative writing. The setting is the time and the location in which the story takes place. These facts set the scene for the story and can determine what kind of conflict occurs. For example, if a story is set in the $1800 \mathrm{~s}$, can the protagonist have a conflict that involves losing his cell phone? The setting can also be important to plot twists if the reader makes assumptions about the time or places that turn out to be false. Overall, the setting has an important impact on every story. 
One last component of narrative writing is point of view. Point of view is the perspective in which the story is told. The two main points of view are first-person and third-person.

\section{Evaluating Student Narrative Text}

There are at least three methods usually used to score writing: holistic method, analytic method and primary trait scoring method (Brown, 2004: 141-146). Analytic method is considered an expert the best method (Brown, 2001: 243) for some reason. Analytic method is considered the best method for some reason (Brown, 2001: 232).

Firstly, analytic method assesses all aspects of writing though the score weight is different. They are contents, organization, vocabularies, language use and mechanic (Dean Brown, 1984: 61-63; Jacob, et al., 1981 in Brown, 2004: 246). In addition, Brown (2001: 356-358) scores the writing based on the content, organization, discourse, syntax, vocabularies, and mechanics while Moreover, Brown and Bailey (1984: 39-41 cited in Brown2 004:244-245) emphasize the aspects of organization, body and conclusion, content, grammar, mechanics, style and expression quality. Secondly, it gives an effective feedback for students and teachers. Thirdly, it is more objective than the other two methods. Therefore, in this research, analytic method was used to assess students writing quality.

The aspects of narrative text to score should consider the characteristic of narrative text. Based on this idea, the aspects of narrative text to score are: the content of story, organization/generic structure, the development of story, language use, vocabularies: verbs and pronouns, and mechanics: spelling, punctuation marks and neatness.

\section{Research Methodology}

The objective of this research is to develop instructional model of narrative writing for the Elementary Education Program of Education Faculty in State University of Makassar. The research was conducted through Research and Development (R\&D) method. It is a research method used to develop and validate educational products (Borg and Gall, 1983: 772; Sugiyono, 2006: 333).

There was Elementary Education Program involved as the samples of target clients taken using cluster random sampling, the time needed to complete the research was very purpose and it spent one year.

There were two types of data collected: quantitative and qualitative data. These data were validated through triangulation technique, i.e., triangulation of data source. The reliability of the questionnaires was analyzed using Alpha Cronbach statistical formula (Djaali and Muljono, 2004: 78-79) indicated that the instruments used were reliable since the reliability coefficient was more than 0.70 (Fraenkle and Wallen, 1990: 136). The reliability of the writing scores was analyzed using inter-rater reliability (Carrol and Hall, 1985: 121-122).

\section{Technique for Analyzing Data}

The data were analyzed in accordance with the type of data collected. The qualitative data related to respondents general view on the model developed and that of the instructional model 
of narrative writing used by the teachers were analyzed qualitatively: data display, reduction and making conclusion.

The quantitative data related to the respondent assessment on the instructional model developed were analyzed using percentage analysis. The focus of this analysis is to find out the percentage of the respondents who agree to the theoretical design of the instructional model of narrative writing developed.

The effectiveness of the final model developed, t-test was used. The prerequisites to apply this statistical formula are: (a) test the objectivity of the scorers using inter-rater reliability and (b) test the variance homogeneity using F-formula. The two samples are assumed to be homogeneous if the value of the F-observed is less than that of the F-table.

The final product of the instructional model developed was considered effective if the value of the t-observed was greater than that of the t-table with the degree of freedom ( $d f) 0 \mathrm{f} \mathrm{N}-2$ and the significance level of 0.95 .

\section{E. Research Findings}

This study could develop and instructional model of narrative writing in English as a foreign language. This Instructional Model is designed based on the following theoretical concepts, students need analysis and some consideration related to the practice of teaching-learning of narrative writing applied as follows:

\section{Theoretical Concepts}

The instructional model of narrative writing in English was developed on the basis of the following theoretical concepts.

a. The topic selection to write in the process on contextual subject matters produce, an expected written text, and the writer needs recursive process.

b. That process involves controlled writing activities to free writing ones

c. Writing activities in the process of language instruction cannot be separated from other language skills: listening, speaking and reading as well as language aspects. Narrative writing is a writing that tells a story, past story or event

d. Writing a narrative text is writing a story

e. The initial stage of the teaching-learning of narrative text is conducted to give opportunities to the students to comprehend the characteristic of narrative text.

\section{Students Need in Narrative Writing Instruction}

Based on the result of need analysis, it was found that in the teaching-learning process of narrative writing, the students need the followings:

a. In this process teaching and learning the student need to learn the model of narrative text before practice writing, 


\section{$\triangle$ Macrothink}

International Journal of English Language Education

ISSN 2325-0887

2016, Vol. 4, No. 1

b. The student need to practice narrative writing based on given model of narrative text, the student needs sharing ideas about new topic before starting writing the student needs writing draft based on the result of discussion.

c. The students need relation of the reaction or response system in correcting their writing both individually and in group, The student needs an opportunity to revise their text and to produce best final text,

d. The student collected and scored based on their learning and the teacher to return the text already scored and teacher to correct the errors in relation to the supporting system,

e. The students need: (a) dictionary, (b) teachers to help the students in learning narrative writing,

d. The nurturing effects the students want to achieve are to improve: (a) grammatical competence and vocabularies, the student needs learn listening ability, reading comprehension, speaking ability to express opinion and writing

e. The student needs to review the use of tenses, the student need to discuss vocabularies related to the topic to write, the student needs to review the use of punctuation marks and the student needs to discuss or review the use of spelling

\section{The Result Instructional Model Development of Narrative Writing}

As descried earlier, this research was aimed at developing instructional model of narrative writing for the students of Elementary Education. Based on the result of preliminary study of this research, the researcher could develop an instructional model of narrative writing for the clients proposed. This instructional model is called narrative writing Model.

\section{a. Instructional Writing Model}

1)The main instructional effect of writing Model developed is proposed to achieve the basic competence of writing as it is stated in the curriculum of English for Elementary Education Program students, i.e., the students are able to produce narrative texts through the stages of rhetorical development using acceptable English. 2)The nurturing effects are to promote: (a) the student cooperation in completing writing tasks, (b) responsibility improvement in completing the writing tasks, (c) students braveness in expressing ideas using oral English, and (d) the integration of students language skill through the teaching-learning of narrative text.

\section{b. Syntax of Writing Model}

The syntax of narrative writing is designed on the basis of the principles below:

1) The teaching-learning process of narrative writing is integrated to other language skill: reading, listening, speaking and language components.

2) The teaching-learning process of narrative writing implemented through the cycles of learning activities

3) The learning process is inductive-deductive process, $\backslash$ 
4) The learning process implemented through studying model of narrative text the generalize the characteristics of narrative text

5) The characteristics of narrative text function, generic structure, and grammatical Characteristics used in the narrative text.

6) Text learning concepts used is individual and mastery learning implemented through the optimally of writing practice and of teacher's roles as a trainer and guide as well as students role as a negotiator.

7) The students are given chance to produce their best narrative writing based on their learning speed.

8) The teaching-learning process of narrative writing is conducted through process-product approach.

9) This is implemented through the continuity of instructional process starting from controlled writing to free writing activities.

10) The students arranging scramble sentences and paragraphs onto a good paragraph.

11) The initial stage of control writing activities is to develop student knowledge on the topic of the given text model and to develop students understanding.

12) The students have comprehended the characteristics of the given narrative

13) The practice writing based on the given text mode to strengthen and apply their understanding.

14) These writing practice involves arranging scrambled sentences or paragraphs taken from the given text model, arranging scrambled paragraphs.

15) These writing practice involves taken from other text and substituting some Elements of the given text model to train student imagination.

16) The students have comprehended the characteristics of narrative text and to write a Narrative text based on the given text model.

17) The Students to continue to practice free writing activities.

18) Free writing activity is to give students learning writing experiences about the stage of writing process.

19) These writing practice the listing interesting topics.

20) This writing practice comparing the topics with friends.

21) This writing practice Choosing one topic to write and writing the draft based on the outline.

22) Discussing the result of peer correction and rewrite the third draft to get the final text Based on the result of discussion 


\section{Macrothink}

23) Editing the draft through proofreading: self-correction and peer correction using the symbols of errors.

\section{c. Instructional Writing Model}

The main instructional effect of Integrated Model developed is proposed to achieve the basic competence of writing as it is stated in the curriculum of English for Elementary Education Program students. The nurturing effects are to promote: (1) the students' cooperation in completing writing tasks, (2) responsibility improvement in completing the writing tasks, (3) students braveness in expressing ideas using oral English, and (4) the integration of students language skill through the teaching-learning of narrative text.

The Effectiveness testing result of the final model the final instructional model of narrative writing in English as a foreign language, called Narratives Writing model was tested its effectiveness compared to the model used by the teachers through the pre-test-posttest control group design, two classes were taken randomly from each class; one class for experimental group and other for control group. The experimental group was taught using integrated model while the control ones were taught using conventional model as the teachers of English usually applied in the teaching- learning of narrative writing. The instructional of narrative writing is assumed effective if the post-test average score of students' narrative writing in the experimental group is significantly greater than that of obtained by the students in the control group, statistically, it is indicated by the value of t-test which is greater than that of t-table with degree of freedom $\mathrm{N}-2$ and the level of significance $0,93 \%$ the data analyzed used ranking order method, it can be conclude that the student's writing model of elementary education program.

The result of testing the effectiveness of integrated model it is found that the average scores of posttest in the experimental groups are significantly greater than those of in the control groups. This is evidenced in values of t-observed which are always higher than those of t-table with the degree freedom N-2 and significance level $85 \%$. This indicates that there is significant difference between students' average scores in the experimental groups and those of in the control groups where the average scores in the experimental groups are greater than those of in the control groups. it means that the writing model is more effective to increase the elementary education program students' ability in writing narrative text in English. This fact shows the writing model is appropriate for the teaching -learning of marrative writing in English as foreign language of elementary education program (PGSD)

\section{F. Conclusion, Implication and Recommendation}

\section{Conclusion}

Based on the result of the research conducted and development (R\&D) method, some conclusion can draw as follows:

a) Effective instructional model to increase the Elementary Education Program students' ability English narrative text, 
b) The instructional effect of English narrative writing instruction must be directed to achievement of the basic competence of writing skills.

c) To achieve the instructional effect, the instructional effect, the instructional process of narrative writing must be supported by instructional circumstances from controlled to free writing activities,

d) Narrative writing must be supported guide and train the student improve their writing so that can produce their, final narrative text as expected based on their learning speed.

e) The instructional process of narrative writing in English as the foreign language must be systematically arranged into two continuous major stages of writing activities: controlled and free writing activities implemented.

f) Narrative writing instruction must give students opportunities to experience the process of narrative writing, starting from controlled to free writing activities by applying and the teacher's role as guide and a trainer.

g) Narrative writing instruction is to give students learning experiences to comprehend the characteristics of narrative text function, generic structure, and language use.

h) The process of narrative writing instruction is conducted through the inductive-deductive learning process.

i) The selection of the topics to write must be contextual

j) The instruction of narratives writing must give students opportunities to publish their final narrative text produce is appropriate for the teaching of narrative writing, the results of validation that the model is effective for the teaching of narrative writing to the Elementary Education Program.

k) The instruction of narratives writing is appropriate a model of instruction for the Elementary Education Program the effectiveness this model was evidenced in the t-test analysis which showed that the value of $t$ - observed was greater than the value of $t$ - table with the degree of freedom N-2 and the significant level 93\%.

\section{Implication}

There is some of these research findings, they are described below: (1) in concerns, with the instruction effect of narrative writing instruction. The research finding makes the teachers conduct the teaching -learning process of narrative writing which must be directed to achieve the basic competence of writing skill itself, not to the mastery of linguistics matters, (2) it deals with the social systems or the circumstance of the teaching-learning of narrative writing, from this side, the research finding makes the teachers implement the social system which is harmonious and interactive learning situation. (3) It is related to the principles of giving responses to the students writing in the instructional process of narrative writing, the pedagogic implication related this component is that it makes the teachers respond to students' writing during the process of writing in order to help them be able to produce their final text. (4) it is related to the supporting system of instruction model of the supporting system of that 
instructional model of narrative writing to this aspect this research finding has an affected to the teachers prepare students' related worksheets in their teaching learning the process of narrative writing so that the students can learn to write systematically.(5) finally, the implication deals with the teaching-leaning stages of narrative write, its implication is that it makes the teacher design and implement their narrative writing instruction by considering the balance between process and product approach, inductive as well as the integration of narrative writing with other language skills.- the deductive learning process, individual and mastery learning concept

\section{References}

Byrne, Donn. (1984). Teaching Writing skills. New e-Edition. London and New York: Longman Group Ltd.

Borg, R. Walter, \& Meredith Damien Gall. (1983). Educational Research: An Introduction, New York: Longman Inc.

Brown, H. Douglas. (2001). Teaching by Principles: An Interactive Approach to Language Pedagogy. White Plains, NY: Addisson Wesley Longman, Inc.

Brown, H. Douglas. (2004). Language Assessment: Principles and Classroom Practices. San Francisco: Pearson Education, Inc.

Carroll, Brendan, J., \& Patrick J. Hall. (1982). Make Your Own Language Tests: A Practical Guide to Writing Language Performance Tests. New York: Oxford University Press.

Djaali dan Pudji Muljono. (2004). Pengukuran dalam Bidang Pendidikan., Jakarta: Program Pascasarjana Universitas Negeri Jakarta.

Dulay, Heidi, Marina Burt, \& Stephen Krashen. (1982). Language Two, New York: Oxford University Press.

Fraenkel, Jack R., \& Norman E. Wallen. (1990). How to Design and Evaluate Research in Education, New York: McGraw-Hill Publishing Company.

Gloria. G., \& Donal R. H. (1999). Write Away. Newbury House Publishers: New York.

Ricahrds, Jack, John Platt, \& Heidi Weber. (1985). Longman Dictionary of Applied Linguistics. England: Longman Group Limited.

Richards, Jack C., \& Theodore S. Rogers. (1986). Approaches and Methods in Language Teaching. Cambridge: Cambridge University Press.

Richards, Jack C., \& Willy A. Renandya. (2002). Methodology in Language Teaching. Cambridge: Cambridge University Press.

Smith, M. Sharwood. (2002). New Direction in Teaching Written English: A TEFL Anthology, Washington, D.C: English Teaching Division Educational and Cultural Affairs. International Communication Agency. 


\section{Macrothink}

International Journal of English Language Education ISSN 2325-0887 2016, Vol. 4, No. 1

Sugiyono. (2006). Metode Penelitian Kuantitatif, Kualitatif dan R\&D. Bandung: Penerbit Alfabeta.

Syah, Nuhibbin. (2006). Psikologi Pendidikan dengan Pendekatan Baru. Bandung: PT Remaja Rosdakarya.

Tomlison, Brian. (2004) Materials Development in Language Teaching. Cambridge: University Press.

Winataputra, S. Udin. (2001). Model-Model Pembelajaran Inovatif. Jakarta: Pusat Antar Universitas,.

\section{Copyright Disclaimer}

Copyright for this article is retained by the author(s), with first publication rights granted to the journal.

This is an open-access article distributed under the terms and conditions of the Creative Commons Attribution license (http://creativecommons.org/licenses/by/3.0/). 